\title{
EL SILENCIO COMO REFERENTE INDIRECTO EN POEMAS NÁUFRAGOS DE DULCE MARÍA LOYNAZ
}

\author{
Humberto López Cruz.
}

\begin{abstract}
RESUMEN
Dulce María Loynaz publicó Poemas náufragos durante la última década de su vida a pesar de haberlos escrito con muchos años de anterioridad. En esta colección, la poeta cubana recurre al silencio como una característica que se repite; al mismo tiempo, el silencio unifica el discurso poético facilitando la trancisión entre el autor real y el autor implícito. Loynaz logra que el silencio, como referente indirecto, ayude a la comprensión de sus poemas.

Palabras clave: Loynaz, silencio, autor real, autor implícito, Poemas náufragos.
\end{abstract}

\begin{abstract}
Dulce María Loynaz published Poemas náufragos during the last decade of her life in spite of having written them many years before. In this collection, the Cuban poet resorts to silence as a characteristic that repeats itself; at the same time, silence unifies the poetic discourse facilitating the transition between the real author and the implicit author. Loynaz manages to make silence, as an indirect referent, help the comprehension of her poems.
\end{abstract}

Key words: Loynaz, silence, real author, implicit author, Poemas náufragos.

...brota del fondo del silencio otro silencio, aguda torre, espada y sube y crece y nos suspende...

"Silencio", Octavio Paz en Libertad bajo palabra

Al completar una lectura inicial de Poemas náufragos de la poeta cubana Dulce María Loynaz (1902- 1997), el lector permanece arraigado a diversos factores que invitan a una meditación ulterior. El silencio es uno de ellos y no es difícil visualizar que este detalle ha sido una característica que, indirectamente, se ha manifestado en los poemas de esta colección.

Ph.D. Humberto López Cruz. Professor of Spanish, University of Central Florida. Área de trabajo: literatura y cultura hispanoamericanas.

Correo electrónico: hlopez@mail.ucf.edu

Recepción: 14- 9- 2007

Aceptación: 22- 10- 2007 
José Ramírez González sostiene que el silencio es algo que no aparece; esto, según él, “otorga automáticamente al Silencio connotaciones metafísicas y existenciales, viniendo a ser así la metáfora de lo inefable o inexpresable" (1992: 23). Es precisamente sobre esta metáfora de lo que no va a expresarse, por designio o incapacidad de lograrse, que este trabajo autentiza su propósito.

Los Poemas náufragos salieron de la imprenta durante los últimos años de la vida de la poeta ${ }^{1}$. No obstante, fueron escritos con significativa anterioridad permaneciendo por décadas sumidos en el mismo alegórico sopor en que se mantenía la imagen de su autora. César López, en el prólogo de la edición de la poesía completa de Loynaz, refiere que estos poemas "son textos salvados de destructivos desastres voluntarios y pasman en su poética prosa que se desenvuelve sin negar ninguna de sus posibilidades, ni las líricas ni las narrativas. [...] ejercicio magistral de quien enseña lo que tiene y puede, ambas propuestas en calidades plenas" (1993: 13)². Loynaz, en la edición, agradece a Pedro Simón el rescate de sus "náufragos" (1993: 7)³. El mutismo literario había estado presente en la obra de Loynaz desde 1958 en que fueran publicados su libro de viajes Un verano en Tenerife y su poema Últimos días de una casa ${ }^{4}$. La década de los noventa estaría marcada por un cambio en cuanto a la asiduidad de sus publicaciones y al reconocimiento que obtendría la poeta de parte del lector y de la crítica. La publicación de La novia de Lázaro por la Editorial Betania de Madrid ${ }^{5}$ y de Poemas Náufragos en Cádiz -donde también aparecería el referido poema ("La novia de Lázaro") como parte de la colección-, marcaría una era de notoriedad para Loynaz donde, entre otros homenajes, recibiría el 23 de abril de 1993 el premio "Cervantes" de manos del rey español Juan Carlos I de Borbón' ${ }^{6}$

La poesía de Loynaz ha sido tildada de hermética (Mateo 1993: 23); sin embargo, es Xiomara Núñez García quien expone un lineamiento fundamental a la hora de acercarse a la obra de la poeta. Ésta indica que "es una constante focalización de la reflexión en el emisor, que a la vez es el yo íntimo del que se nutre su poesía, por lo que asistimos a la identificación entre autor real y autor implícito" (1999: 40). Este ensayo propone repasar cómo el emisor se afianza en el silencio para lograr la comunicación con el lector y, al mismo tiempo, obtener una conexión entre ambos autores -real e implícito-, que defina esta poesía. El espacio que existe a partir de nuestra realidad y lo imaginado, muchas veces intanglible, se funde en una prosa poética bien organizada que orienta al lector en la dirección correcta. No es el propósito de Loynaz confundir ni alterar los significados; ella misma insiste en que "[m]i poesía es limpia y concisa y está escrita para todo el mundo", para rematar, "[p]or eso todo el mundo me la entiende" ("Mi poesía: autocrítica" 1993b: 17). El reto de entendimiento se afianza en la simplicidad de los hechos: a pesar de la supuesta facilidad de comprensión, su poesía oculta sus referentes internos que deben ser descodificados. Es acertado partir de la base que Loynaz busca un lector activo que responda a su prosa poética.

Virgilio López Lemus acierta al señalar que la poesía de Loynaz cuenta con breves silencios que aparecen diseminados en su obra; además, indica la presencia de puntos suspensivos que subrayan dicho silencio (2000: 19). Es también muy importante su juicio sobre su poesía al decir que es:

\footnotetext{
Una poesía capaz de tender el puente comunicativo autor-lector aun cuando no se participe de su aprehensión filosófico-religiosa de la vida. Lograrlo no es fácil, porque en la praxis una obra no es independiente del credo o de la concepción del mundo en que se apoya el poeta. Para llegar a ese grado de comunicación, requiere el autor de una tensión espiritual nada común, de un don expresivo realmente universal; sobre todo cuando es el propio yo-íntimo del que se nutre su poesía (22-23).
} 
Es necesario destacar que el silencio metafórico no desapareció con las ediciones de la obra de Loynaz que inundaron las librerías a raíz de conocerse el fallo del "Cervantes". En el caso de Poemas náufragos, a los que Janet Pérez cataloga de viñetas o cuentos líricos (1995: 11), el silencio en cuestión unifica estos poemas en prosa para formar una estructura que definirá la colección. No es posible decir que sea una manifestación de lo inexistente; muy por el contario, en esto se fundamenta lo tangible, algo que Loynaz ha expuesto y que requiere la incorporación del lector. Thomas J. Bruneau indica que el silencio parece ser un concepto y un proceso de la mente (1973: 17); al mismo tiempo, cita a John Cage quien observa que dentro del ámbito de la comunicación no hay tal cosa como el silencio absoluto, algo siempre está pasando que emite un sonido" (1973: 17). No obstante, esto legitima la presencia y existencia del silencio en Poemas náufragos. Compárese la aseveración previa, desde la perspectiva del lector, con los ruidos del océano donde no exista otra voz que la de un náufrago entre los elementos; lo único que oirá será el silencio de su propia presencia. Los náufragos, léase poemas, hablan a través de su silencio? .

En "Dos Nochebuenas" (1992: 51- 70) hay una marcada división entre los espacios que Loynaz intenta recrear. La poeta va a reescribir su encuentro con dos ciudades disímiles unidas ahora a través de su voz poética: Granada y La Paz. En ambos encuentros hay una heterogeneidad de silencios que la prosa poética sublima para moldear su entorno; es lo inexpresable: no es necesario describir lo que se puede deducir. Esta omisión no se interpreta como algo que Loynaz no quiere decir; más bien consiste en un enunciado que el texto va a resaltar sin que aparezca de una forma explícita. Las siguientes citas corresponden a la primera parte del poema; o sea, a la Granada que ve Loynaz, la ciudad que se abre ante el lector a través de una tercera persona; el autor implícito se hace evidente. Por ende, la experiencia del lector está supeditada a la voz poética: "[h]a habido un silencio súbito y extraño, solemne casi.......] He pasado en Granada unos días que pudiera llamar ensimismados: Días vagos, aislados en mi vida". [...] En el silencio de la callejuela los asnos rebuznan melancólicamente. [...] Soledad y silencio: La noche se viene arriba, deprisa, cargada de presentimientos..." (1992: 53- 56). Las meditaciones de Loynaz se reproducen en el texto y el lector presiente una necesidad de encuentro con una imagen que el subconsciente no llega a captar; la poeta no se abre ante el espacio que está descubriendo, más bien murmura las reacciones que fuerza en ella la Granada que percibe. Algo similar nos recuerda Claudio Guillén en su análisis sobre la poesía de Antonio Machado: el primer silencio que se encuentra concierne a la propia persona (1971: 243). Hay que observar los puntos suspensivos en los momentos en que la poeta parece que va a descubrir ese ápice de información que necesita para ir armando su imaginario rompecabezas, artilugio que no cobrará vida puesto que otro interés, tal vez, ha desviado la atención de Loynaz. El pensamiento poético avanza a una mayor velocidad que la interpretación de las imágenes que percibe; hay un silencio de aceptación del entorno. En este momento, autor real e implícito se funden en un solo referente; la voz poética se reviste de la melancolía identificada en los asnos para presentir lo que el lector debe visualizar al comulgar con Loynaz sobre la experiencia granadina. La semipresencia de la poeta es, según Guillén, apropiada a la textura temática del trabajo (1971: 240). Al traer a colación las palabras de Loynaz se puede constatar que ese silencio no es un texto omitido sino las pautas para una mejor comprensión del mismo. El relato de Granada es un cuadro hecho de apreciaciones, pero son impresiones desde el silencio narrativo que se insertan en la prosa poética a partir de la carencia de diálogo. Es un silencio paradójico, pues aunque no cuente con una voz audible desde la óptica física, las palabras pronunciadas por el autor implícito contribuyen a establecer 
un diálogo con el autor real que, repito, se fundamenta en el silencio. A pesar de la facilidad de comprensión aludida por la propia Loynaz al referirse a su obra poética, el lector puede preguntar si el silencio demarca la frontera de ambigüedad establecida por la confluencia de lo real e implícito en el texto. George Steiner afirma que el lenguaje tiene sus límites fronterizos y que uno de los modos de expresión con los que bordea es el silencio; además, añade que éste puede constituir una tentación para el escritor (1967: 39). El poema es la clave para acceder al mundo que Loynaz propone: un espacio de búsqueda; un encuentro con otra dimensión. Sus palabras indican: "[p]or la poesía damos el salto de la realidad visible a la invisible, el viaje alado y breve, capaz de salvar en su misma brevedad la distancia existente entre el mundo que nos rodea y el mundo que está más allá de nuestros cinco sentidos" (1993b: 13). El lector ha presenciado una visión de Granada diferente; la experiencia de Loynaz se ha transmitido en el poema y ha encapsulado una imagen de la ciudad quizás ajena a la realidad de la misma, pero que se asienta en la interpretación que, de la ciudad andaluza, ha visualizado la poeta.

La segunda parte de "Dos Nochebuenas" es el recuento de un recorrido por las calles de La Paz. El lector acompaña a la poeta en un viaje donde las imágenes se multiplican y los silencios abundan. El yo-íntimo sugerido por ambos críticos, Núñez García y López Lemus, se manifiesta en la impresión que las calles paceñas van dejando en el subconsciente de Loynaz; la poeta recoge el silencio de los habitantes y lo fusiona con el suyo propio. Tomemos estos fragmentos: "[t]odos los niños indios son iguales. [...] Y ninguno llora. Traen ya el silencio metido entre los huesos. [...] Es el suyo también un baile silencioso, un poco rígido, un poco hierático. Y cosa extraña, no ríen al bailar; sus caras permanecen con la misma expresión de siempre, o mejor dicho, sin ninguna expresión, apretados los labios, fijos los ojos" (1992: 61- 65). El metafórico puente de López Lemus se ha materializado, a través del silencio, para establecer el engarce necesario entre el yo y el otro. Julia Kristeva expresa que el otro que descubrimos es la cara oculta de nuestra identidad (1991: 9). El nexo aludido ha sido alcanzado y el primer silencio, el de la poeta como autor implícito, es compartido por el receptor; es su lado oculto que está en contacto con el otro y como parte de la revelación observa que comparten el silencio desde siempre: Loynaz lo desarrolla al andar por las calles de La Paz; los indios paceños, al llevar a cabo sus bailes. Ambas expresiones son muestras de su respectivo yo-íntimo que quedan solidificadas en el texto para un lector que acepta la forma de llevar a cabo el viaje alado hacia una realidad invisible, sugerido por Loynaz, donde el silencio se manifiesta como referente indirecto del poema.

No es éste el único ejemplo encontrado. "Poemas del insomnio" (1992: 45- 49) constituye una buena manifestación del silencio a través del emisor, tal como ha expresado Nuñez García, que reflexiona en su desplazamiento para lograr la cohesión necesaria. La ausencia del ruido pone en duda si el silencio es tangible, mas aquí se puede confirmar que este modo de expresión es el único que bordea el texto; el silencio se muestra como un espacio inviolable que envuelve a la narradora permitiendo que aflore tras el velo de su subjetividad. Es cierto que el yo-íntimo vuelve a representarse, pero esta intimidad se manifiesta en el silencio para agudizar su elocuencia. El poema en sí es un rezo, un monólogo por parte de la poeta que intenta hablar con un ente superior para, por medio del ruego, obtener una gracia. La poeta habla implícitamente, el silencio se perfila como lo sublime del instante; el lector desconoce si la petición será escuchada y la dádiva concedida; sin embargo, sí se sabe que el silencio ha acompañado a la voz poética a lo largo del poema. El lector debe asumir la postura de Loynaz en su plegaria y caminar junto a ella el sendero de su angustia: "[c]omo he velado 
toda la noche, el día de hoy se me ha unido al de ayer; se quedaron por tanto dos días sin línea divisoria entre sí, soldándose uno al otro hasta ya hacerse ambos un solo día grande, amorfo, innominado" (1993: 46). A pesar del lector ser testigo de una letanía interminable, es menester señalar que el silencio es el factor que delimita el poema, la frontera sugerida por Steiner; la poeta habla, pero su voz rebota en el vacío de lo inexpresable. Loynaz configura el poema de forma que sea un largo monólogo donde la intimidad de su angustia intente asirse a un oído receptivo que comprenda su desesperación. La afirmación de Marilyn Bobes sobre la obra poética de Loynaz en general se puede aplicar a este poema en particular, ya que refiriéndose a Loynaz indica que "hilvana el poema desde el silencio de su intimidad, como un inmaculado bordado del que salta el diseño preciso con sus colores exactos" (1984: 68). El diseño aludido se enmarca dentro de un ensamblaje que es característico en Loynaz, especialmente si se lee en conjunto la armazón que forman sus poemas en prosa, donde el silencio vuelve a desempeñar un papel preponderante. La poeta lo inserta en la prosa poética como esencia pura de su propio ser: "[s]i me quitas el sueño, me habrás quitado el modo de volver a aquel primer silencio donde mi voz tuvo raíz y dónde sólo me es ya posible alimentarla” (1992: 48- 49). El retorno a su silencio hace que éste actúe, una vez más, como el referente indirecto del que se nutre la voz poética y que constituya un elemento unificador que identifique esta colección de náufragos.

El primer poema que da comienzo al texto, "El enemigo" (1992: 9- 13), representa otro ejemplo del tema en discusión y que, curiosamente, se diferencia de "Poemas del insomnio" en cuanto a las voces que hablan en el texto. En éste último, es la voz suplicante la que se escucha en todo momento implorando la gracia divina. En "El enemigo" es la voz poética, o voz narrativa que relata este poema en prosa, la que conversa con el lector a fin de contar la historia del guerrero. A pesar de ello, el lector accede a la verdadera personalidad del individuo en cuestión por medio de los silencios que Loynaz ofrece. Ramírez González mantiene que "[e]1 poder social ha estado tradicionalmente asociado al derecho a hablar, a dejar hablar y a hacer callar" (1992: 29), para continuar: "[t]odo régimen social [...] desarrolla sus propias técnicas para administrar la palabra, imponer silencio y regular las relaciones entre significantes y significados" (1992: 30). El poema lleva de epígrafe el proverbio árabe que alude al que se sentará a la puerta de su tienda para ver pasar el cadáver de su enemigo (1992: 9). El momento llega y el personaje asume el poder que le concede la derrota de su antagonista; como resultado, se autoimpone el silencio, un silencio de reflexión que va durar la extensión del poema. Veamos los siguientes fragmentos: "Allá abajo en el valle amanecía... Han pasado muchos días y muchas noches. [...] Y fue largo el invierno aterciopelado que ahuyentó las últimas golondrinas... [...] Luego volvió la primavera a abrir sus remolinos de aire... Luego... [...] Muchas noches...-¿Vamos a contar las estrellas?...-Y de pronto viene el cadáver del Enemigo..." (1992: 10- 11). Este poema en prosa está compuesto de una multiplicidad de oraciones breves separadas por silencios que hacen al narratario, y por consiguiente al lector, meditar la situación del protagonista. El poder ha sufrido un cambio y ahora el régimen social, dentro de su propia estructura, asocia el silencio con la sabiduría de la meditación. El significante del silencio que hubiera podido tener el significado de la espera mientras el enemigo vivía, ahora ha cobrado otra dimensión ante el recién enfrentado cadáver: obliga a la reflexión; aunque el significante sea el mismo, el lector descubre que hay más de un significado. La voz poética acompaña al individuo en sus meditaciones para culminar en su análisis sobre la situación presente: “[c]aía la tarde mansamente; el hombre azorado, decepcionado, infinitamente abatido seguía mirando el cadáver de su enemigo... Pasó una golondrina volando... La herida -su herida- ancha, negra, 
desolada, se iba llenando de la sombra de la noche... Y entonces el hombre lloró" (1992: 13). Al final del poema el silencio es roto por el llanto del protagonista como resultado del proceso de reflexión llevado a cabo. Loynaz vuelve a utilizar sus recursos poéticos; el mejor ejemplo es la pluralidad de puntos suspensivos para recalcar unos silencios que, indiscutiblemente, van a disponer el ensamblaje del poema. Si aceptamos la propuesta de Umberto Eco que indica que las leyes que gobiernan la interpretación textual son la leyes de un régimen autoritario que guía al individuo en sus acciones (1984: 52), entonces no será difícil admitir que Loynaz ha organizado el poema de modo que el silencio se proyecte indirectamente, pero que, al mismo tiempo, dirima cualquier controversia en el desenvolvimiento de la trama e indique al lector las pautas necesarias para su entendimiento ${ }^{8}$. El poder que otorgó al individuo el derecho a dejar de hablar, en su momento le permitió romper el silencio motivado por su propio llanto; el silencio de la reflexión consiguió su propósito.

La reescritura del pasaje bíblico que Loynaz ofrece en "El primer milagro" (1992: 39- 42) transporta al lector al comienzo de la vida pública de Jesús tal como indican los evangelios. Alessandra Riccio sostiene muy acertadamente que en la poesía de Loynaz se hallan "las mutaciones mínimas dentro de temas mínimos, recovecos de la vida, de la historia, de la religión, que logran, gracias al poder taumatúrgico de su poesía, desplazar lo imposible hacia lo posible, hacer presencia de la ausencia y hacer visible el vibrar de la flecha que apunta certera hacia lo angélico, hacia lo que no es posible percibir con los cinco sentidos" (1993: 28). Hay que ver cómo se puede incorporar este juicio a "El primer milagro" teniendo en consideración la intromisión del silencio como emisor responsable de los desplazamientos del texto.

El tema es conocido: el primer milagro de Jesucristo tal y como aparece narrado por los evangelistas: la conversión de agua en vino en las bodas de Caná9. Loynaz es consciente que el lector conoce el desenlace del pasaje, sólo busca revelar un vértice no explorado para aproximarse al hecho. Es ahí donde el silencio se intercala para, permítase la paradoja, hablar por los personajes involucrados. Es menester leer cuidadosamente la sucesión de eventos que jalonan la historia para destacar cómo el silencio, siempre como emisor, sufre los desplazamientos necesarios para afirmar el orden del poema sin que su esencia se diluya en el texto. La voz poética, como autor implícito y asumiendo la perspectiva de María, habla de la novia: "[a] ella como era mujer, no se le escapó la mirada de angustia de la novia al levantar la tapa de los cántaros. La había visto poner luego silenciosamente los mismos cántaros de vino sobre la mesa mientras su mirada aleteaba en el aire como una paloma que acaba de descubrir que está perdida" (1992: 39). Seguidamente, el silencio apunta hacia María en su petición de madre: "[h]abía en los ojos que lo miraban, un ruego inocente, que él mismo no acertaba a comprenderlo. [...] En aquel instante la madre se le ha vuelto niña y él tiene miedo de herirla con una palabra seca, con un gesto, con esa facilidad con que se hiere a los infantes... Pero ella quiere nada menos que un milagro" (1992: 40). De aquí el silencio se traslada a la figura del Hijo que va a resolver el conflicto; no sin antes Jesús reflexionar silenciosamente sobre el papel que debe desempeñar: "[n]o se atreve a decirlo, pero es lo que ella quiere, lo que insinúan los ojos confiados que lo miran. [...] No lo dice, pero de todos modos se resiste tratando de suavizar su negativa" (1992: 40- 41). Finalmente, el silencio regresa al origen del conflicto representado esta vez en la pareja de recién casados: "[a]llí estaban los novios mirándose turbados, descubiertos de pronto en la intimidad de su pobreza, temerosos de incurrir en la mofa o el desdén de sus invitados" (1992: 41). Luis Jiménez, en la poesía de Loynaz, conecta 
la mirada, como tropo, con su antítesis: el silencio, destacando a su vez la visibilidad del lenguaje poético (1992: 136). Las imágenes presentadas reflejan en el silencio la metáfora de lo inexpresable expuesta, con anterioridad, por Ramírez González; no obstante, es un silencio que unifica la conexión implícita entre las voces que discurren en el poema. Loynaz no está interesada en acentuar la magia del milagro, sino el prodigio del momento. La taumaturgia aludida por Riccio apunta hacia la expresión poética, no hacia el resultado del milagro.

Es curioso destacar el análisis que presenta Lucía Melgar sobre el silencio en la obra de Elena Garro; aquí la crítica lo califica de "silencio expresivo" (2000: 357). Pero más importante, Melgar refiere que "[e]l silencio, en un sentido más amplio es, a la vez, polo opuesto y complemento de la palabra" (2000: 357). Este juicio encaja en "El primer milagro" ya que Loynaz utiliza un silencio expresivo como elemento didáctico de su poética; no es lo omitido en el texto, sino lo expresado. El poema tiene necesidad del silencio y la poeta lo facilita para lograr una simbiosis constructiva con la palabra que a su vez apoye el discurso poético. Marcelo Abadi sostiene que "el silencio no se opone al lenguaje. Es una de sus modulaciones, uno de sus términos" (1985: 111). Esta habilidad de recursos facilita la fluidez a una prosa en la que se diluye la poesía de Loynaz vista en sus textos precedentes. El silencio, a pesar de constituir un referente indirecto, dirige la armazón del poema y su elocuencia impide una aproximación textual que intente prescindir del mismo; es el suplemento necesario que establece junto con la palabra la fusión pertinente que culmina en un nuevo significado a pesar de provenir de un pasaje conocido, y de un final anticipado, por todos.

El final de este ensayo es el último poema que aparece en Poemas náufragos: "La novia de Lázaro" (1992: 73- 79). Éste es, quizás, el mejor ejemplo para corroborar cómo el silencio incorpora su voz y garantiza la solidez del poema. No sugiero que haya características nuevas, en cuanto al uso del silencio se trata, que no hayan sido vistas con anterioridad en la poesía de Loynaz sino la consolidación de este recurso como fenómeno estético. En "La novia de Lázaro" no tan sólo complementa la palabra sino que la palabra parece depender del silencio; éste crea una aureola de misticismo que abarca la longitud del poema y a la que para penetrar se necesita no sólo aceptar el desplazamiento del texto, sino tener pendiente que será, en todo momento, el silencio el emisor implícito. El lector tiene ante la vista otro milagro de Cristo; no se ve la taumaturgia en el hecho divino ya realizado, léase la resurrección de Lázaro, sino la desesperación de la novia. Se ha dicho que "[1]a obra es un himno a la desilusión, el fracaso y la desdicha que acompaña desde una perspectiva ontológicamente desventurada al ser humano" (De Feo 2004: 148). Es la novia la que cuestiona en todo momento la situación en la que se encuentra; o mejor aun: la situación en que la han situado. El personaje está desubicado y Loynaz, en pleno dominio de su prosa poética, fusiona significante y significado para lograr que el silencio se erija como referente. Fijémonos en la siguiente cita: "[c]omo el primer amanecer del mundo... Eso es, y hay que ajustarse a eso. [...] Tuve una noche larga... ¿No comprendes? Tú estabas muerto y yo estaba viva; [...] Conmover la muerte... Eso yo pretendía. Conmover a la Inconmovible, a la Ciega, a la Sorda, a la Muda..." (1992: 76- 77). Loynaz se afirma en unos sentidos que no deben delimitar el alcance de la poesía, según sus palabras citadas con anterioridad, para destruir las aspiraciones de su heroína. No hay respuesta de la muerte; el poema hace que el silencio se estrelle en la repetida queja de la novia; o mejor dicho: el silencio vuelve a ser la frontera de Steiner y es la respuesta que recibe la protagonista.

Hay que recordar lo citado por Bruneau donde niega la existencia del silencio absoluto porque siempre algo está pasando; la muerte, en su continuado mutismo, recurre al silencio como única respuesta. De Feo sugiere que "podría interpretarse como una resurrección de la 
alteridad, del otro yo de la conciencia de la novia que busca en el símbolo de Lázaro la propia resurrección de un ideal sublime perdido" (2004: 150- 51). El ideal aludido está perdido por más que ella se aferre al imposible del recuerdo; por más que piense, hable, musite, solamente escucha el silencio como complemento en el diálogo que sostiene consigo misma; el espacio fronterizo donde se lleva a cabo la intersección entre el lenguaje y el silencio. No hay más que acercarse a uno de los últimos parlamentos proferidos por la novia para constatar el alcance de su derrota y de la victoria de Loynaz como artífice del texto. Su imaginaria conversación con el Lázaro resucitado, el que nunca aparece ni se sabe si está presente en el texto, establece la yuxtaposición necesaria entre sujeto y objeto que debe afirmarse en el silencio: "[s]i fueras tú quien a tu vez me hablaras sorda, me besaras fría, me sacudieras rígida... Tú quien me sorprendiera muerta, muerta sí, inexorablemente muerta hasta en la sonrisa, liberada ya de cuanto pudiera ser gloria o tragedia en nuestro destino..." (1992: 79). En la búsqueda del espacio que reclama para sí, la novia se encuentra ante la impotencia del no existir; la nulidad de su presencia se trasmuta en el silencio que debe escuchar Lázaro, pero que ciertamente percibe el lector. Mariela Gutiérrez destaca que es soledad "lo que siente la novia, angustia amarga y sola que le ha dejado la pérdida de su novio, Lázaro" (2005: 265). Es factible añadir que la soledad se afirma en la inexistencia del personaje, no tan sólo desde la perspectiva evangélica donde se omite cualquier alusión posible a la novia de Lázaro, sino desde la realidad de la mujer dentro de los límites del poema. Es la realidad de su irrealidad; una situación inexpresable que establece una existencia ficticia y que el personaje no podrá eludir ${ }^{10}$. Desde el título a la última oración del poema se demarca una frontera fantasmagórica que intenta captar la anuencia del lector en conceder, al menos, una duda sobre la existencia de la protagonista. La identidad de la novia se diluye dentro de un laberinto ilusorio donde cada corredor parece conducirla a la nada y, paradójicamente, constatar su propia irrealidad. No en balde al final del poema la novia reclama su resurrección (1992: 79); es el último grito para intentar incluirse dentro de un mundo que no la considera parte del mismo y que le responde con el acostumbrado mutismo. Loynaz orienta el poema haciendo que la protagonista llame desde su muerte para intentar lograr la atención que en su momento despertara Lázaro como difunto en el seno de la comarca; una vez más, quedan ahogadas las aspiraciones de la novia que debe enfrentar una doble muerte, real y simbólica, donde el silencio será su único acompañante.

La publicación de Poemas náufragos significó no tan sólo el rescate de unos poemas que de otra forma hubieran desaparecido sin dejar rastro, sino también otro despliegue de control poético proveniente de la pluma de Loynaz. A pesar de haber ido a la imprenta durante la última década de la vida de la poeta, los náufragos fueron la muestra ideal para acercarse a las distintas etapas de su vida; una selección que combinaría su sensibilidad artística con el dominio de la palabra. Esta vez me he aproximado a esta colección a través de la vertiente del silencio; al mismo tiempo, soy consciente de la variedad de enfoques críticos que permite este poemario. El silencio visto ha sabido responder como el emisor que logra la conexión entre autor real e implícito y lector; un referente indirecto que estructura la cohesión deseada. La metáfora de lo inexpresable impide la evanescencia de una prosa poética que se afirma a partir de su singularidad; las omisiones deliberadas se erigen como la fortaleza del texto: lo simbólicamente subrayado sin explicitud. O, tal vez, pueda expresarlo en otras palabras: un silencio que nos ha hablado en voz alta. 


\section{Notas}

1. Los Poemas Náufragos no sólo aparecen en la edición gaditana, de donde provendrán todas las citas que se incluyan en este estudio a menos que se indique lo contrario, sino que fueron parte también de la edición de la Poesía completa de Loynaz, editada por César López (1993: 161- 92). Asimismo, una selección de los mismos compuesta por "El enemigo", "Poemas del insomnio", "Envidia" y "La novia de Lázaro" formó parte de la Antología lírica editada por María Asunción Mateo (1993: 245- 61). Remito a cualquier lector interesado a que consulte estas ediciones. A su vez, deseo aclarar que por razones de espacio sólo comentaré los siguientes poemas: "Dos Nochebuenas", "Poemas del insomnio", "El enemigo", "El primer milagro" y "La novia de Lázaro".

2. En la introducción a la Antología lírica editada por María Asunción Mateo, ésta señala que la colección debe su título "al hecho de que se salvaron, ente otros, de los muchos que Dulce María destruyó para que nunca se publicaran. Corresponden a distintas épocas de su vida, podría decirse por tanto que es una recopilación de sus escritos" (1993: 35). Obsérvese que algunos de los poemas llevan al final el año de su publicación.

3. La presencia de Pedro Simón en la obra de Dulce María Loynaz es notable. Además del mencionado "rescate" de los Poemas náufragos, Simón es responsable, entre otros, del estudio indispensable Dulce María Loynaz por Pedro Simón de la serie Valoración Múltiple, así como de la selección de versos que forman Poemas escogidos (1993 Madrid: Visor; 1993 Madrid: Fondo de Cultura Económica). En el primer texto, Simón anuncia en el prólogo que los Poemas náufragos "[s]egún testimonio de la autora, este libro estaría integrado por varios poemas extensos escritos en prosa, pero con un tratamiento muy distinto a los Poemas sin nombre" (10). Además, Simón reproduce una entrevista con Loynaz quien comenta que dichos poemas "fueron escritos al azar, en distintas épocas y sin ánimo de integrar ningún libro. Al paso del tiempo he visto que pudieran iniciar una forma nueva de poesía y esa sería su justificación. Me alegré porque mi obra es bastante reducida no sólo porque he escrito poco sino también porque he desechado más de la mitad de lo escrito. Precisamente estos poemas se llaman náufragos porque se salvaron de ser desechados con muchos otros que por una razón u otra no quise que algún día llegaran a publicarse. (Desechar significa desde luego, destruir)" (64-65). Considero que esta cita es fundamental para entender mejor el origen de estos poemas.

4. Ya en 1955 se había publicado su Obra lírica (1955, Madrid: Aguilar) con una nota preliminar de Federico Carlos Saínz de Robles. Esta edición contenía los poemarios, previamente publicados por separado, Versos 1920-1938, Juegos de agua y Poemas sin nombre. No obstante, sería en 1958 que aparecerían Últimos días de una casa -contiene tan sólo un largo poema homónimo que le da el nombre al texto- (1958 Madrid: Imprenta Hermanos Soler) y Un verano en Tenerife (1958 Madrid: Aguilar). Tras estas efemérides la obra de Loynaz caería en el ya mencionado sopor literario que duraría tres décadas.

5. Quiero destacar que La Editorial Betania, dirigida por Felipe Lázaro, publicó La novia de Lázaro como un texto independiente donde solamente aparecía el mencionado poema. De ahí que algunas veces veamos el nombre como título de libro, en cursiva, y otras como título de poema, entre comillas. En este trabajo uso ambas formas, dependiendo la procedencia del comentario. He consultado las dos publicaciones del poema aunque, como indicara en una nota precedente, las citas sobre "La novia de Lázaro" provendrán de Poemas náufragos.

6. Dulce María Loynaz recibió en 1993 el premio "Cervantes” que le había sido concedido en 1992. Véase el artículo de Clara Isabel de Bustos en el madrileño diario $A B C$ para repasar las palabras del rey Juan Carlos I al comentar tan significativo evento para las letras hispanoamericanas. 
7. Antes de comenzar a examinar los poemas individualmente, quiero referir al lector a lo que en su momento escribiera Enrique Saínz con relación a la publicación de los náufragos: "[d]iríase obra de madurez y es ciertamente coetáneo del resto de su quehacer, un conjunto en el que no se pueden establecer con facilidad épocas y etapas" (1998: 54). Estas palabras se hallan en el capítulo "Para una lectura de Dulce María Loynaz" (1998: 38- 65) y pueden servir como una aproximación genérica a unos poemas que, a pesar de poseer lugares comunes dentro de la poética de Loynaz, tienen la sensatez artística propia de una poesía cuidadosamente elaborada.

8. Para una mejor comprensión de la propuesta ofrecida por Eco, sugiero al lector que consulte el capítulo "The Poetics of the Open Work" (1984: 47- 66) en el referido texto The Role of the Reader. Varios de los puntos sugeridos por Eco pueden aplicársele a la poética de Loynaz.

9. Véase la sección del Nuevo Testamento de la Biblia, preferentemente el Evangelio según San Juan (2.12.12) para tener a mano el pasaje de las bodas de Caná.

10. En su estudio sobre la poesía de Eugenio Montale, Clodagh Brook sugiere que el poeta asocia la idea de lo inexpresable con una condición fundamental de la existencia (2002: 30). Esto puede muy bien aplicársele a "La novia de Lázaro" como poema. Sugiero al lector interesado que repase el texto de Brook, especialmente la sección en la que intenta identificar lo inexpresable como tal (2002: 29- 47).

\section{Bibliografía}

Abadi, Marcelo N. 1985. Observaciones sobre el silencio y la palabra. Buenos Aires: Torres Agüero.

Bobes, Marilyn. 1984. "Dulce María Loynaz: la poesía del silencio”. Revolución y cultura. 7: 68- 69.

Brook, Clodagh J. 2002. The Expression of the Inexpressible in Eugenio Montale's Poetry. Oxford: Clarendon Press.

Bruneau, Thomas J. 1973. "Communicative Silences: Forms and Functions". The Journal of Communication. 23: 17- 46.

Bustos, Clara Isabel de. 1993. "El Rey subraya la pasión de Dulce María Loynaz por nuestra lengua y su amor por España”. ABC 24 abr.: 53.

De Feo, Miguel Ángel. 2004. "Un himno de desilusión: la representación de la conciencia desdichada en La novia de Lázaro de Dulce María Loynaz". Dulce María Loynaz: cien años después. Humberto López Cruz y Luis A. Jiménez (eds.). Madrid: Editorial Hispano Cubana, 147- 60.

Eco, Umberto. 1984. The Role of the Reader. Bloomington: Indiana University Press. 
Guillén, Claudio. 1971. "Stylistics of Silence”. Literature as System: Essays Toward the Theory of Literary History. Princeton: Princeton UP, 221-79.

Gutiérrez, Mariela. 2005. “Por qué resucitaste?: Muerte y sexualidad en La novia de Lázaro”. La mujer en la literatura del Mundo Hispánico. Juana Alcira Arancibia (ed.). Westminster, CA: Instituto Literario y Cultural Hispánico, 263- 73.

Kristeva, Julia. 1991. Extranjeros para nosotros mismos. Xavier Gispert (trad.). Barcelona: Plaza \& Janes.

López, César. 1993. prólogo. Poesía completa. Por Dulce María Loynaz. La Habana: Editorial Letras Cubanas, 5- 13.

López Lemus, Virgilio. 2000. Dulce María Loynaz: estudios de la obra de una cubana universal. Tenerife: Centro de la Cultura Popular Canaria.

Loynaz, Dulce María. 1991. La novia de Lázaro. Madrid: Editorial Betania.

1992. Poemas náufragos. Cádiz: Diputación provincial de Cádiz.

1993a. Antología Lírica. María Asunción Mateo (ed.). Madrid: Espasa-Calpe.

1993b. "Mi poesía: autocrítica". Anthropos. 151: 13- 17.

1993c. Poesía completa. César López (ed.). La Habana: Editorial Letras Cubanas.

Mateo, María Asunción. 1993. Ed. e Introducción. Antología Lírica por Dulce María Loynaz. Madrid: Espasa-Calpe, 13- 40.

Melgar, Lucía. 2000. "Silencios expresivos. Gamas y matices del silencio en la obra de Elena Garro". Monographic Review/Revista Monográfica. 16: 357- 67.

Núñez García, Xiomara. 1999. "La reflexión metapoética de Dulce María Loynaz”. Islas. 41.121: 40- 49.

Paz, Octavio. 1990. Libertad bajo palabra [1935-1957]. 2a ed. Enrico Mario Santí (ed.). Madrid: Cátedra.

Pérez, Janet. 1995. "Vida, poesía y existencia de Dulce María Loynaz". Letras femeninas 21 (1- 2): 9- 19.

Ramírez González, José L. 1992. "El significado del silencio y el silencio del significado”. El silencio. Carlos Castilla del Pino (ed.). Madrid: Alianza Editorial, 15- 45. 
Reina Valera (ed.). 1983. La Biblia. Nashville: Holman Bible Publishers.

Riccio, Alessandra. 1993. "La poesía como taumaturgia”. Anthropos. 151: 28- 31.

Saínz, Enrique. 1998. Indagaciones. La Habana: Editorial Letras Cubanas.

Simón, Pedro. 1991. Dulce María Loynaz por Pedro Simón. Serie Valoración Múltiple. La Habana: Ediciones Casa de las Américas.

Steiner, George. 1967. Language and Silence. New York: Atheneum. 